\title{
(1 THE PILGRIMAGE OF ROBERT LANGTON
}


LONDON : HUMPHREY MILFORD

OXFORD UNIVERSITY PRESS 


\section{THE PILGRIMAGE OF ROBERT LANGTON}

\section{TRANSCRIBED WITH AN}

\section{INTRODUCTION}

\section{AND NOTES}

BY

E. M. BLACKIE, B.A.

CHAPLAIN TO THE KING, ARCHDEACON OF STOW CANON AND PRECENTOR OF LINCOLN CATHEDRAL

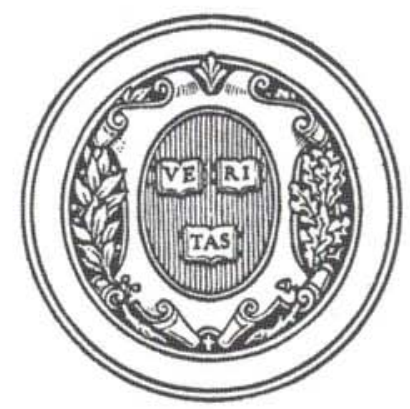

CAMBRIDGE

HARVARD UNIVERSITY PRESS

I 924 
COPYRIGHT, I924

BY HARVARD UNIVERSITY PRESS

PRINTED IN U.S.A. 